\title{
Anthropogenic modifications to a barrier island influence Bonnethead (Sphyrna tiburo) movements in the northern Gulf of Mexico
}

\author{
Andrea M. Kroetz ${ }^{1,2 *}$, Sean P. Powers ${ }^{1,2}$, J. Marcus Drymon ${ }^{1,2}$ and Kyeong Park ${ }^{3}$
}

\begin{abstract}
Background: Barrier islands are dynamic features of the northern Gulf of Mexico that are affected by natural processes and more frequently, anthropogenic disturbances. In addition to providing a barrier from storms, these islands offer habitat for many marine species. In an effort to prevent oiling of the Alabama coastline following the Deepwater Horizon oil spill, an artificial rock-rubble berm was constructed in 2010 to reconnect two portions of Dauphin Island, a northern Gulf of Mexico barrier island that was separated during Hurricane Katrina. An acoustic array established prior to the closure of "Katrina Cut" was used to investigate the potential effect of this anthropogenic alteration on the movement patterns of acoustically tagged Bonnetheads (Sphyrna tiburo).

Results: Across the entire acoustic array, the largest proportion of detections occurred on receivers before construction at Katrina Cut (0.55), followed by the period after the construction (0.25), and the period during the construction (0.20). Focusing on the area near Katrina Cut, the two hydrophones in this area had the highest proportion of detections before construction (0.10), followed by the period during construction (0.02), and then the period after construction and closure of Katrina Cut $(<0.01)$. The post-closure location of highest activity for Bonnetheads shifted westward following the closure of Katrina Cut. Salinity values from a hydrographic model were higher at the Katrina Cut location in 2010 when the cut was open compared to 2011 and 2012 when the cut was closed, a potential explanation for the observed changes in Bonnethead distribution.

Conclusions: Fluctuations in salinity post-closure of Katrina Cut may effect Bonnethead movements, although other factors, including seasonal migrations and/or the redistribution of their preferred prey, may also be important. Regardless of the mechanism, this rapid shift in distribution of Bonnetheads highlights the potential effect of anthropogenic activities on sharks using coastal environments.
\end{abstract}

Keywords: Acoustic telemetry, Movement patterns, Shark, Salinity, Katrina Cut

\section{Background}

Numerous species of elasmobranch fishes use the dynamic habitat provided by coastal ecosystems. Nearshore habitats can be highly productive, supporting a high biodiversity of fishes and invertebrates [1], common prey resources for coastal elasmobranchs. Understanding the degree to which small coastal elasmobranchs use these nearshore habitats can lead to better

\footnotetext{
*Correspondence: akroetz2@gmail.com

2 Dauphin Island Sea Lab, 101 Bienville Blvd, Dauphin Island, AL 36528, USA

Full list of author information is available at the end of the article
}

management and conservation, and strengthen our ability to predict how changes in environmental factors will affect these populations [2-4]. Shifts in habitat with ontogeny and/or as a response to environmental stressors can make evaluating habitat use, as measured by time spent in an area by a species, difficult. However, advances with in situ biotelemetry allow for movements of fishes to be monitored over extended time periods and across numerous habitats [4].

Numerous factors can influence nearshore habitat use by coastal elasmobranchs [5]. Abiotic factors like temperature and salinity can affect distribution and habitat 
use of many coastal elasmobranch species including Bonnetheads (Sphyrna tiburo, [6]), juvenile bull sharks (Carcharhinus leucas, $[7,8]$ ), and juvenile sandbar sharks (Carcharhinus plumbeus, [9]). For example, controlled releases of freshwater from the Caloosahatchee River greatly affected salinity levels within Pine Island Sound, FL. Movements and distributions of acoustically tagged Bonnetheads were monitored during these freshwater releases, and Bonnetheads shifted to areas of the estuary that were higher in salinity [6]. In addition to abiotic factors, anthropogenic alterations can change nearshore environments and negatively affect coastal species. For example, populations of the endangered smalltooth sawfish (Pristis pectinata) have declined dramatically, largely the result of bycatch and habitat loss [10]. On the other hand, anthropogenic alterations may be beneficial to other coastal species. In Texas, a dredged channel created a tidal connection between the Gulf of Mexico (GOM) and the Upper Laguna Madre. This allowed for significant ingress of the nekton of commercially important species to habitats that were previously inaccessible, potentially increasing production [11]. Anthropogenic alterations to natural coastlines may be beneficial or detrimental to a suite of coastal species; however, the impact of such modifications remains unknown without dedicated, species-specific monitoring.

Bonnetheads are small coastal sharks found in estuarine and coastal waters of the Atlantic Ocean and GOM [12]. Bonnetheads are long-term residents of coastal estuarine systems [13] and exhibit site fidelity to certain estuaries, often returning to these areas after extended periods of time $[14,15]$. Species that exhibit such site fidelity provide an opportunity to examine how environmental changes affect movement patterns [14]. While factors that influence Bonnethead movements have been well studied in the eastern GOM $[6,16]$, comparatively less is known about the movements of this species in the northern GOM [but see 17]. Identifying the region-specific factors influencing the distribution of this species is essential for understanding potential impacts induced from anthropogenic alterations to coastal ecosystems.

Both anthropogenic (e.g., coastal development) and natural (e.g., hurricanes) disturbances can change the geomorphology of coastal habitats $[18,19]$. These shifts can affect environmental conditions, thus affecting species using nearshore habitats [20]. As these disturbances to coastlines become increasingly common, it is imperative to investigate the potential impact these alterations have on species that reside in these habitats. Herein, we provide data on Bonnethead movements in response to the artificial closure of a natural passageway in a barrier island. Our objectives were twofold. The first objective was to assess residency and moment patterns of
Bonnetheads across coastal Alabama. Our second objective was to investigate if an anthropogenic alteration to natural coastline affected the movement patterns of Bonnetheads in that same region. Using acoustic telemetry we were able to show a relatively rapid shift in Bonnethead movement in response to an anthropogenic alteration.

\section{Methods}

\section{Ethics statement}

All research was conducted in accordance with the University of South Alabama (USA) animal ethics protocol 437256 for fish telemetry. This research was approved by the Institutional Animal Care and Use Committee (IACUC) and the state of Alabama authorities. All sharks were supplied with flowing seawater during tagging procedures and were handled quickly and carefully. No additional samples were taken from sharks during tagging procedures.

\section{Study area}

Located at the mouth of Mobile Bay in the northern GOM, Dauphin Island AL is $23 \mathrm{~km}$ long and $2.8 \mathrm{~km}$ wide at the widest point [20]. In 2005, Hurricane Katrina fragmented the main body of Dauphin Island creating a 2.5-km-wide and 3-m-deep gap in the island known as Katrina Cut $[19,20]$. Katrina Cut formed a direct connection between the GOM and Mississippi Sound allowing for water exchange and ingress/egress of marine organisms (Fig. 1a). Katrina Cut remained open for 5 years until it was artificially closed in 2010 following the Deepwater Horizon explosion (DwH), which occurred on April 20, 2010. The DwH released approximately 5.0 million barrels of oil into the GOM [21]. Concern that the oil passing through Katrina Cut would contaminate the oyster beds and estuaries in Mississippi Sound prompted the Alabama Department of Environmental Management to initiate an emergency response project [22]. Construction to close Katrina Cut with a $2.5-\mathrm{km}$-long sand-filled, rock-rubble berm began in July of 2010 with the gap effectively closed (i.e., no water exchange, berm fully in place) in late December of 2010. Final construction of the rock-rubble berm was completed in April 2011 (Fig. 1b).

\section{Acoustic array}

An acoustic array, deployed as part of the Coastal Alabama Acoustic Monitoring Program (CAAMP), was initiated in 2009 to track the movements of several species of elasmobranchs $[8,23]$, including Bonnetheads. This array was comprised of 35 Lotek Wireless Hydrophone System (WHS) omni-directional acoustic receivers (Fig. 2). In addition to the CAAMP array, Science Applications International Corporation (SAIC) deployed 38 


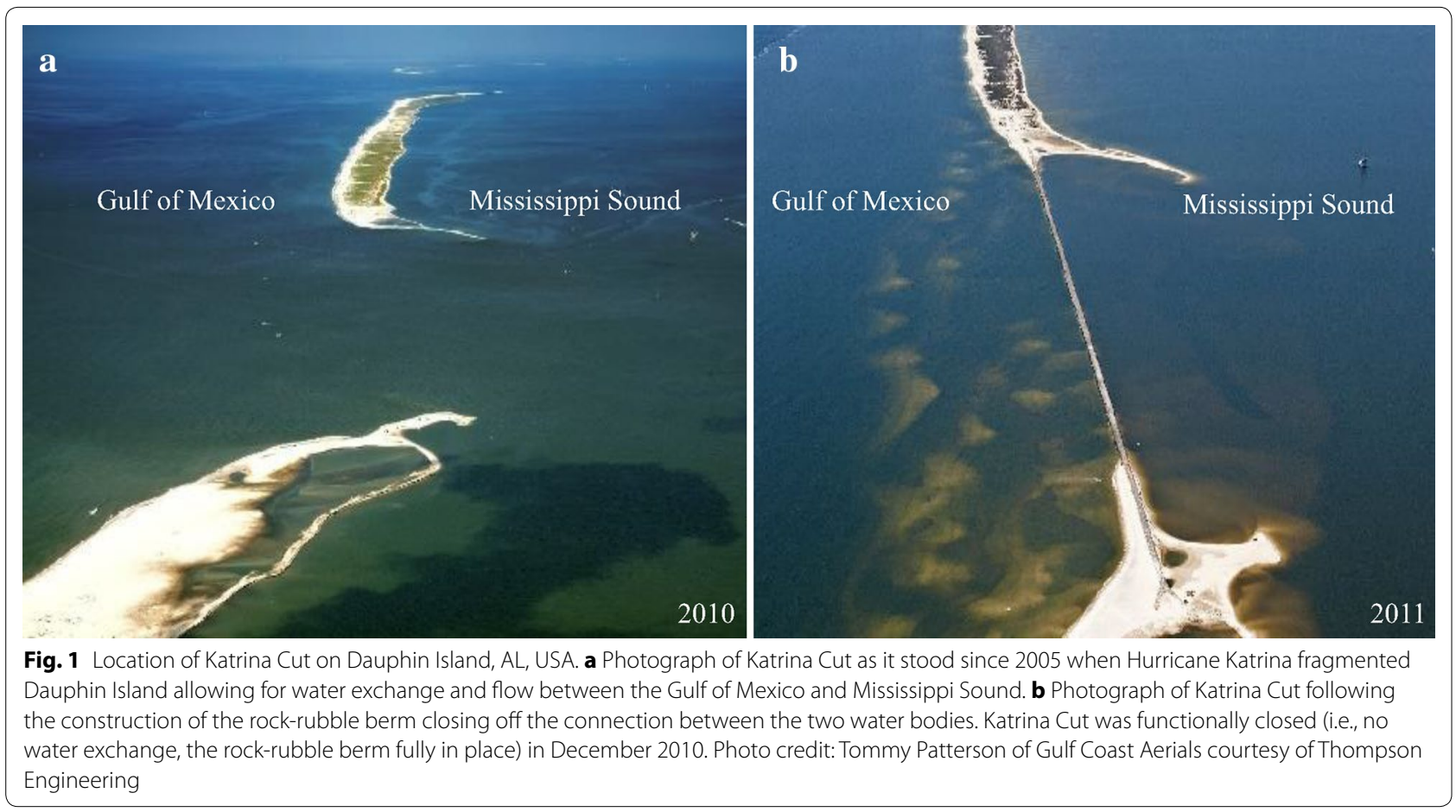

Vemco VR2W receivers along the Gulf Islands National Seashore Barrier Islands and Dauphin Island (Fig. 2). The Vemco receivers (hereafter known as the SAIC array [24]), were deployed by SAIC and Eglin Air Force Base Natural Resources Section to evaluate migration patterns of Gulf Sturgeon (Acipenser oxyrinchus desotoi). While the complete SAIC array spanned a large area between Lake Pontchartrain, LA and Cedar Key, FL, this study only included the receivers along the barrier islands in the north central GOM and Mississippi Sound as these were the receivers that detected Bonnetheads. Two receiver types were used in the CAAMP array; Lotek WHS $2000(\mathrm{n}=30)$, which can detect frequencies at $69 \mathrm{kHz}$ (Rcode) and Lotek WHS $3050(\mathrm{n}=5)$, which can detect frequencies at $76 \mathrm{kHz}$ (MAPcode). The SAIC array deployed Vemco VR2W receivers $(n=38)$, which detect frequencies at $69 \mathrm{kHz}$. As such, all three receiver types were capable of detecting transmissions from the multi-mode tags implanted in Bonnetheads (see below). The receivers in the CAAMP array were deployed at the major corridors around Mobile Bay and Mississippi Sound across multiple habitat types including sand, mud, and sparse seagrass coverage. Because of strong currents and high vessel traffic in the region of deployment, the majority of the receivers were attached to channel makers at depths from 3.0 to $7.0 \mathrm{~m}$ to minimize potential loss. Data were downloaded from the CAAMP receivers bimonthly and receiver performance over a wide range of hydrographic conditions was monitored by range testing conducted six times between March and October 2010 (for a detailed description of range testing see [8]). Range tests of the Lotek acoustic receivers showed that the primary receiver type used in our study, the WHS2000, had a detection distance ranging from 0 to $400 \mathrm{~m}$ with the most detections received between 150 and $300 \mathrm{~m}$. The WHS3050 receivers had a detection range between 0 and $300 \mathrm{~m}$ with detections decreasing with increasing distance from the receivers (for detailed results see [8]). Long-term range testing of the VR2W receivers occurred in the GOM over an 8-month period between 2009 and 2011 [24]. These data demonstrated that detection capability was greatest at $350 \mathrm{~m}$ and decreased out to $500 \mathrm{~m}$. Detection ranges of the Lotek and Vemco receivers did not overlap with the exception of two receivers at Katrina Cut (Fig. 2). The acoustic array was deployed prior to the DwH and subsequent closure of Katrina Cut, which created a unique opportunity in this study. Bonnethead movements were being monitored prior to anthropogenic alterations to the coastline and were continuously monitored throughout the construction and completion of the rock-rubble berm.

\section{Specimen collection and tagging}

Field sampling occurred in the coastal and estuarine waters around Dauphin Island, AL, USA. Targeted gillnet sampling was used to collect Bonnetheads for acoustic tagging. Once captured, sharks were carefully removed from gillnets and were measured (precaudal, fork, and 


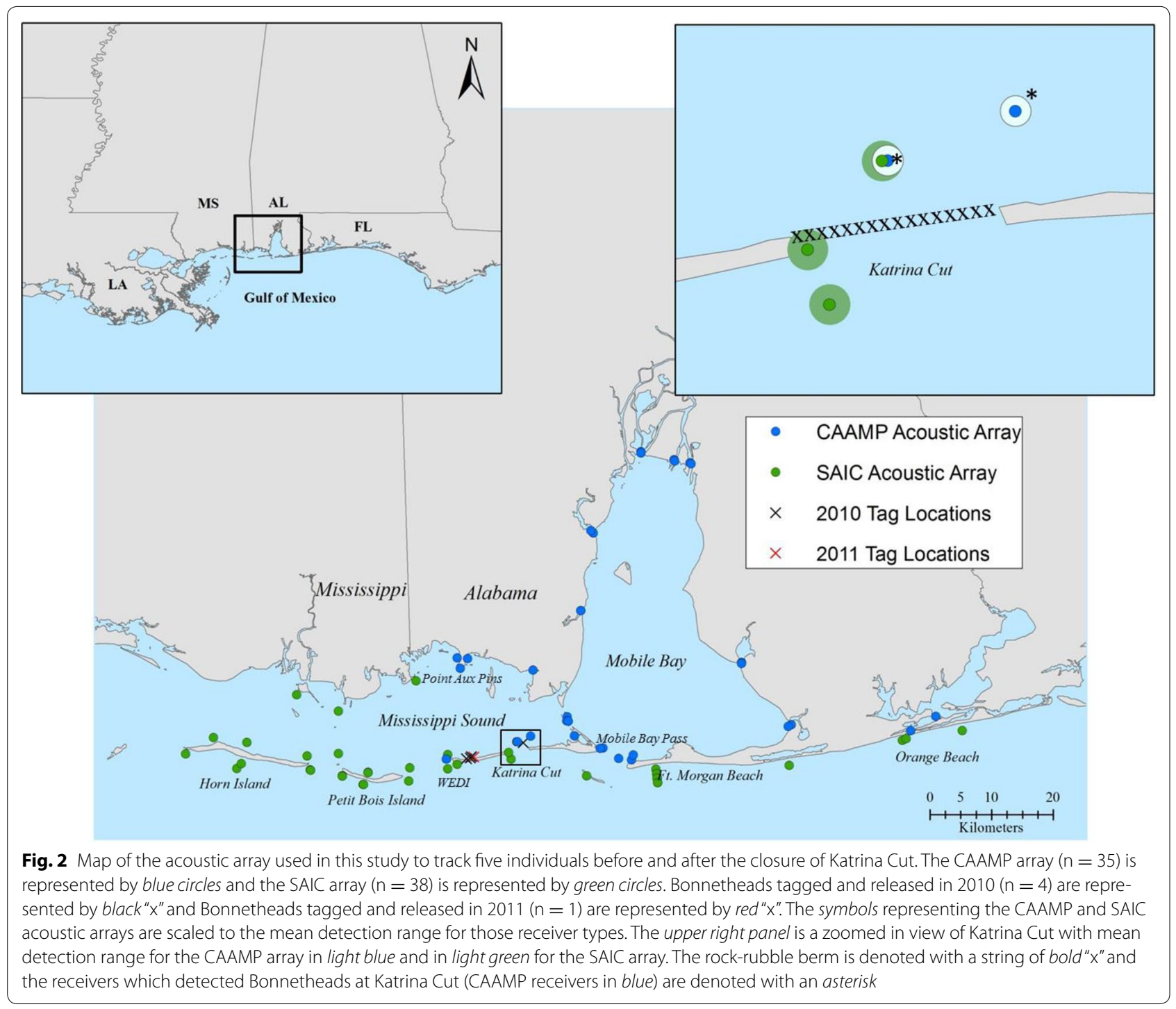

total length in $\mathrm{mm}$ ), weighed (to the nearest $\mathrm{kg}$ ), sexed, and tagged. Maturity in females was estimated from data on fork length (FL, mm) at $50 \%$ maturity [25] and maturity in males was determined by external characteristics of claspers following the methodology of Clark and von Schmidt [26]. Sharks were tagged with two tag types; an external, plastic swivel tag (Dalton ID, Henley-onThames, UK) and an internal ID only acoustic tag (Lotek model MM-MR-16-50, $16 \times 80 \mathrm{~mm}, 35 \mathrm{~g}$ in air, tag life estimated 389 days). The acoustic tags were multi-mode transmitters that emitted two ID codes: every $60 \mathrm{~s}$ on an Rcode frequency $(69 \mathrm{kHz})$ and every $5 \mathrm{~s}$ on a MAP code frequency $(76 \mathrm{kHz})$. A small $13-\mathrm{mm}$ incision was made above the abdominal midline for insertion of the acoustic tag into the peritoneal cavity of the sharks. Once the tags were implanted, the incision was closed with surgical sutures (3.0 Ethicon Prolene monofilament) and an antiseptic wipe was applied. The same tagging locations were used before and after the closure of Katrina Cut; near the west end of Dauphin Island and near Katrina Cut (Fig. 2). Eleven Bonnetheads were tagged in 2010 and nine were tagged in 2011.

\section{Data analysis}

Data from the acoustic array were analyzed to determine residency and movement patterns of Bonnetheads before, during, and after the construction of the rockrubble berm that closed Katrina Cut. "Before" Katrina Cut refers to the period of time when Katrina Cut was open prior to construction of the berm (May 2010-early 
July 2010) while "after" Katrina Cut refers to the period of time when the cut was completely closed and construction of the berm was completed (May 2011-June 2012). "During" Katrina Cut refers to the period of time when construction of the berm was underway and includes a period when the cut was open (mid July 2010-December 2010) as well as when the cut was functionally closed off (December 2010-April 2011). Detections logged on the hydrophones were analyzed as proportions of each tagged individual, i.e., the proportion of detections was calculated for individual sharks and then averaged for each receiver. The occurrence of tagged Bonnetheads was plotted to provide a visual timeline of presence throughout the study. To determine residency, Bonnetheads were considered present in the study area if more than one detection occurred on any given receiver within a single day. Days at liberty were calculated as the difference between the time when a Bonnethead was first detected in the array and the time of the last detection within the array. Detection data were plotted in ArcMap GIS (ESRI ArcView 10.1) to visualize overall detections and relative receiver use within the array.

To visualize differences in Bonnethead movement patterns before, during, and after construction of the rock-rubble berm at Katrina Cut, we applied inverse distance-weighted (IDW) interpolations in ArcMap GIS. The IDW measures the complete set of values (i.e., proportion of detections) surrounding prediction locations (i.e., receivers in the array). Measured values that were closer to the prediction location were weighted higher than those farther away. Locations where activity was the highest were determined using 50 and $90 \%$ contours of the interpolated values for periods before, during, and after the construction of the rock-rubble berm at Katrina Cut.

\section{Salinity modeling}

A three-dimensional hydrodynamic model previously developed for coastal Alabama including Mobile Bay and eastern Mississippi Sound was available for this study [27]. The model, when forced by observed open boundary water levels, freshwater discharge, and wind gave a good representation of the observed surface elevation, current velocity, and salinity for both total and subtidal components [27]. The model was also shown to reproduce the observed salinity in the Cedar Point Reef area at the eastern end of Mississippi Sound for 2 years in 2008-2010 [20]. We used this model to simulate salinity variations before and after the closure of Katrina Cut. Model simulations were conducted for the years 20102012 to encompass the entirety of this study, with Katrina Cut open in 2010 and with it closed in 2011-2012. The forcing conditions of the model runs were prepared following the procedures described in Kim and Park [27] and Park et al. [20].

\section{Results}

\section{Detections}

Twenty Bonnetheads were implanted with acoustic transmitters between May 2010 and May 2011; however, we focused on a subset of tagged individuals that were detected before and after the closure of Katrina Cut $(\mathrm{n}=5)$. The size of the five tagged sharks ranged from 670 to $765 \mathrm{~mm}$ FL (mean $=738 \mathrm{~mm} \mathrm{FL} \pm 17 \mathrm{~mm}$ $\mathrm{SD}$ ), and included four mature females and one mature male (Table 1). Four of the Bonnetheads were captured and released at the west end of Dauphin Island and one individual was captured and released near Katrina Cut (Fig. 2).

Bonnetheads were detected from May-October in 2010, March-September in 2011, and March-April in 2012 on both the CAAMP and SAIC acoustic arrays. We received 2539 individual detections from 2010 to 2012 from the five tagged Bonnetheads and detection locations were dispersed along the barrier islands of Alabama and Mississippi (Fig. 3). The overall individual proportion of detections within the acoustic array were variable during the study period (Fig. 4). Of the five sharks monitored, shark 10167 contributed to the highest proportion of detections (0.41), followed by shark $10143(0.27)$, shark 10274 (0.23), shark 10131 (0.09), and shark 10132 (0.01).

Table 1 Tagging and biological data for acoustically tagged Bonnetheads detected within the acoustic array

\begin{tabular}{|c|c|c|c|c|c|c|c|c|c|}
\hline Tag ID & $\mathrm{FL}(\mathrm{mm})$ & Sex & Maturity & $\begin{array}{l}\text { Date } \\
\text { tagged }\end{array}$ & $\begin{array}{l}\text { Salinity } \\
\text { (psu) }\end{array}$ & $\begin{array}{l}\text { Temperature } \\
\left({ }^{\circ} \mathrm{C}\right)\end{array}$ & $\begin{array}{l}\text { Detection } \\
\text { year }\end{array}$ & $\begin{array}{l}\text { Days at } \\
\text { liberty }\end{array}$ & $\begin{array}{l}\text { Number days } \\
\text { detected }\end{array}$ \\
\hline 10131 & 746 & $\mathrm{~F}$ & $M$ & 8/6/2010 & 24.2 & 32.6 & 2010 & 13 & 7 \\
\hline 10132 & 753 & $\mathrm{~F}$ & $M$ & 5/13/2010 & 25.4 & 24.6 & 2010, 2011 & 313 & 3 \\
\hline 10143 & 765 & $\mathrm{~F}$ & $M$ & $5 / 11 / 2010$ & 24.7 & 26.7 & 2010, 2011 & 401 & 30 \\
\hline 10167 & 670 & $\mathrm{~F}$ & $M$ & $6 / 1 / 2010$ & 20.5 & 26.8 & 2010 & 76 & 42 \\
\hline 10274 & 755 & $M$ & $M$ & $5 / 18 / 2011$ & 20.8 & 24.4 & 2011,2012 & 345 & 34 \\
\hline
\end{tabular}

Days at liberty signify the time from when a shark was first detected to when it was last detected within the array. Salinity and temperature values represent the abiotic factors that were present at the time of capture and tagging. Four sharks were collected, tagged, and released at the west end of Dauphin Island and one individual was tagged near Katrina Cut 


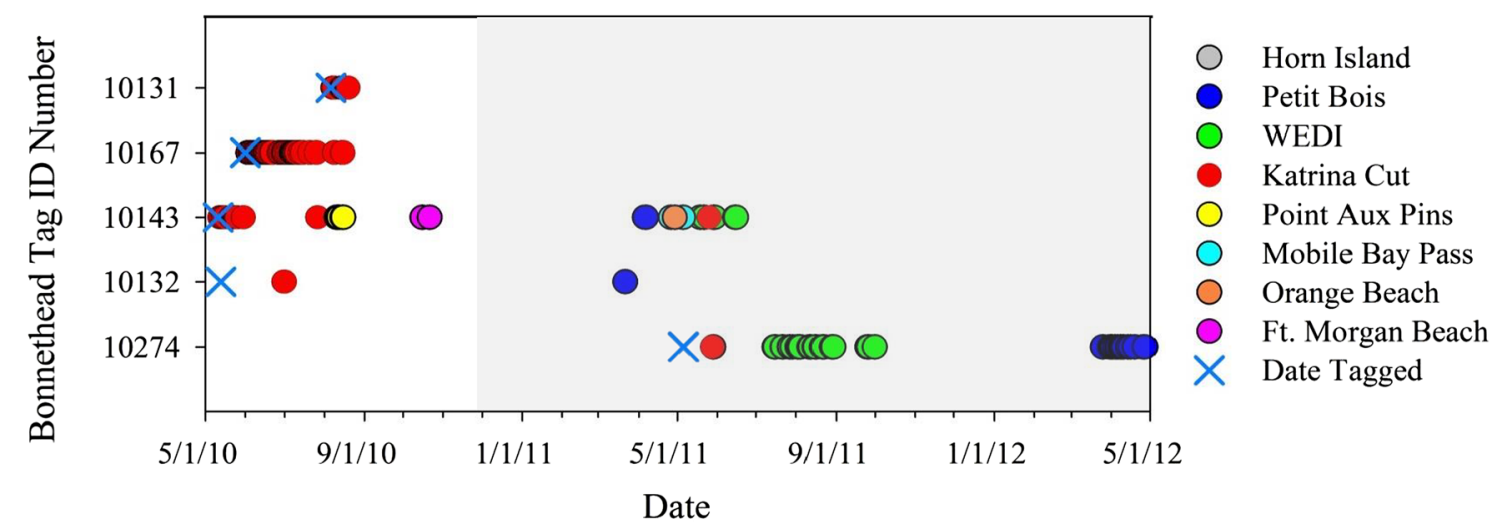

Fig. 3 Presence of acoustically tagged Bonnetheads from 2010 to 2012. Locations where Bonnetheads $(n=5)$ were detected are color coded to correspond to the general regions labeled in Fig. 2. Blue " $X$ " represents the date that tags were deployed on the sharks. The gray shading represents the time when Katrina Cut was functionally closed (December 2010)

Across the entire acoustic array, the largest proportion of detections occurred on receivers before construction at Katrina Cut (0.55), followed by the period after the construction (0.25), and the period during the construction (0.20). Focusing on the area near Katrina Cut, the two hydrophones in this area had the highest proportion of detections before construction (0.10) (Fig. 4a), followed by the period during construction (0.02) (Fig. 4b), and then the period after construction and closure of Katrina Cut $(<0.01)$ (Fig. 4c). Days at liberty ranged from 13 to 401 days (Table 1 ) with the mean days at liberty as 230 days ( $\pm 173 \mathrm{SD})$. Three of the five tagged Bonnetheads returned to the array in consecutive years; two individuals tagged in 2010 prior to the construction at Katrina Cut returned to the array in 2011 and one individual tagged in 2011 after the closure of Katrina Cut returned in 2012. In the combined CAAMP and SAIC array ( $\mathrm{n}=74$ hydrophones), Bonnetheads were detected on 14 of the receivers in eight general locations (Fig. 3). We received detections from Bonnetheads in spring, summer, and fall before, during, and after construction of the rock-rubble berm at Katrina Cut.

\section{Movement patterns}

All five Bonnetheads displayed interesting movement patterns during this study. For example, Bonnethead 10143 remained at Katrina Cut prior to construction of the rock-rubble berm from the time that it was tagged through the end of May 2010. This individual was not detected in our array in June, but once construction began in July, this individual returned to Katrina Cut for several hours and then shifted its movement to the northeastern part of Mississippi Sound in August. It then moved eastward to Fort Morgan Beach in October before detections ceased for 2010. The same individual returned in 2011 further west to Petit Bois Island where it remained for 1 day in April before moving to Ft. Morgan, then Orange Beach where it subsequently returned to the west end of Dauphin Island. This shark returned to Katrina Cut briefly (i.e., hours) before leaving the location in favor of the west end of Dauphin Island (a supplemental video file shows this in more detail, see Additional file 1). Bonnethead 10132 displayed similar movement behaviors, but to a lesser degree, remaining at Katrina Cut for 1 day in 2010 and returning in 2011 to Petit Bois Island. Bonnetheads 10131 and 10167 remained at Katrina Cut for the entire time that we received detections, including the period before and during construction of the rock-rubble berm. Bonnethead 10274 was tagged after the construction of the berm at Katrina Cut, remained at this location for several hours before moving west to the end of Dauphin Island and then returning even further west to Petit Bois and Horn Islands the following year. Bonnetheads 10132, 10143, and 10274 typified a general westward shift in movement from the time that Katrina Cut was open to the time that it was closed with some individuals remaining at Katrina Cut until it was closed.

Inverse distance-weighted interpolations showed clear differences among the time periods before, during, and after construction of the rock-rubble berm at Katrina Cut. Prior to the closure of the cut, both 50 and $90 \%$ locations of highest activity were located at Katrina Cut corresponding to the time before and during construction (Fig. 5a, b). Following the closure of the cut, both 50 and $90 \%$ location of highest activity shifted west to the location of Petit Bois Island corresponding to the time period after construction was completed (Fig. 5c). 


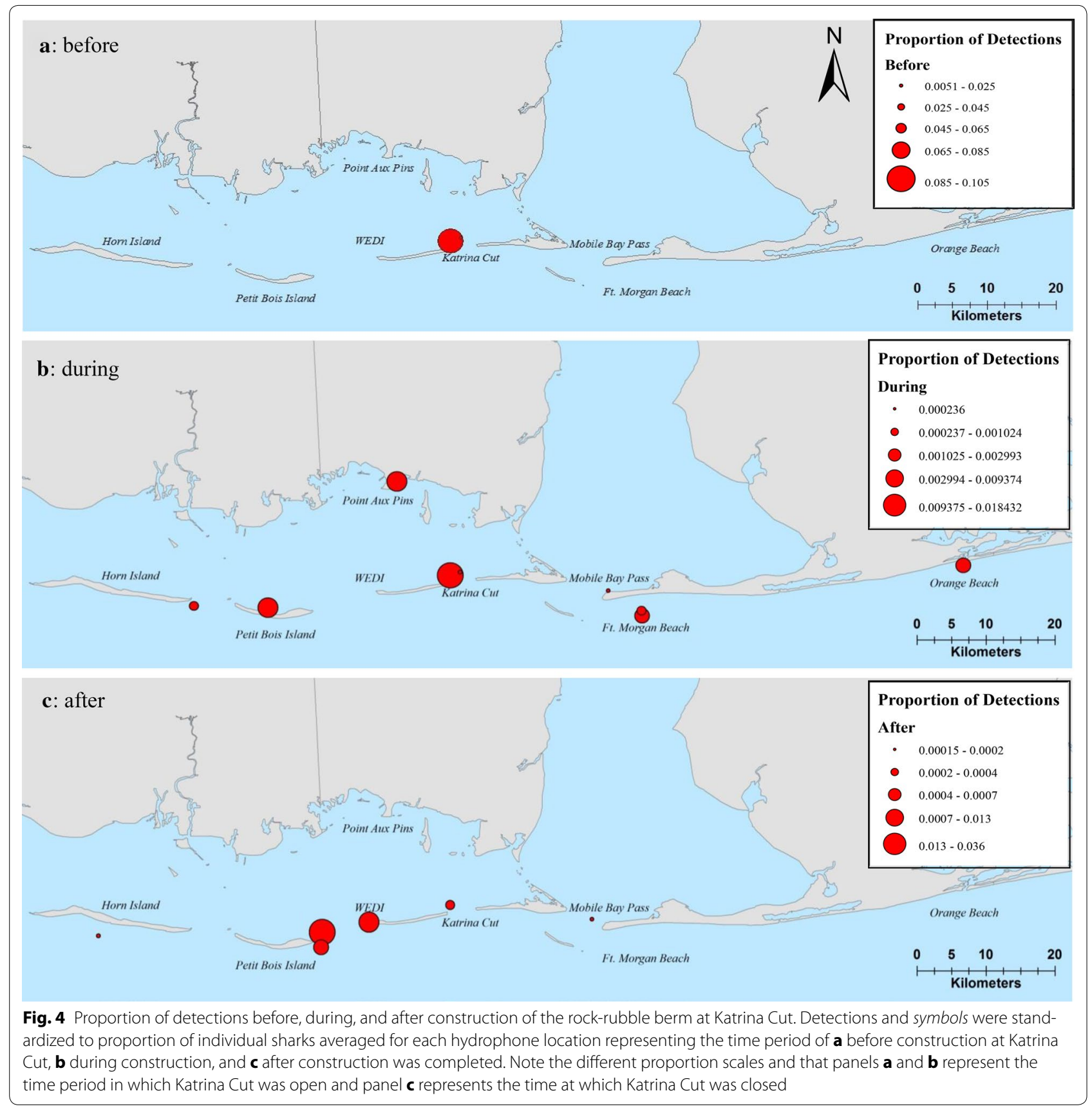

\section{Salinity model}

Daily freshwater discharge into Mobile Bay and modeled salinity at a location approximately $50 \mathrm{~m}$ inside of Katrina Cut showed clear differences in surface and bottom salinities (Fig. 6). There were notable differences before (2010) and after (2011-2012) the closure of the Katrina Cut. Salinity was estimated to fluctuate in response to freshwater discharge with high discharge lowering the salinity but the salinity rebounded as discharge decreased at both the surface and the bottom. Tidal signals in salinity were evident in 2010 when tidal currents were flowing through Katrina Cut; however, tidal signals were not as clear in 2011-2012 when there was no tidal current through Katrina Cut. During the periods of sustained low river discharge during summer, both surface and bottom salinities showed little variation in 2011 (without Katrina Cut), but there were clear tidal signals with Katrina Cut open in 2010. Salinity, which was low during the discharge peaks, increased as freshwater discharge decreased (Fig. 6). Both surface and bottom salinities readily recovered to almost pre-peak 


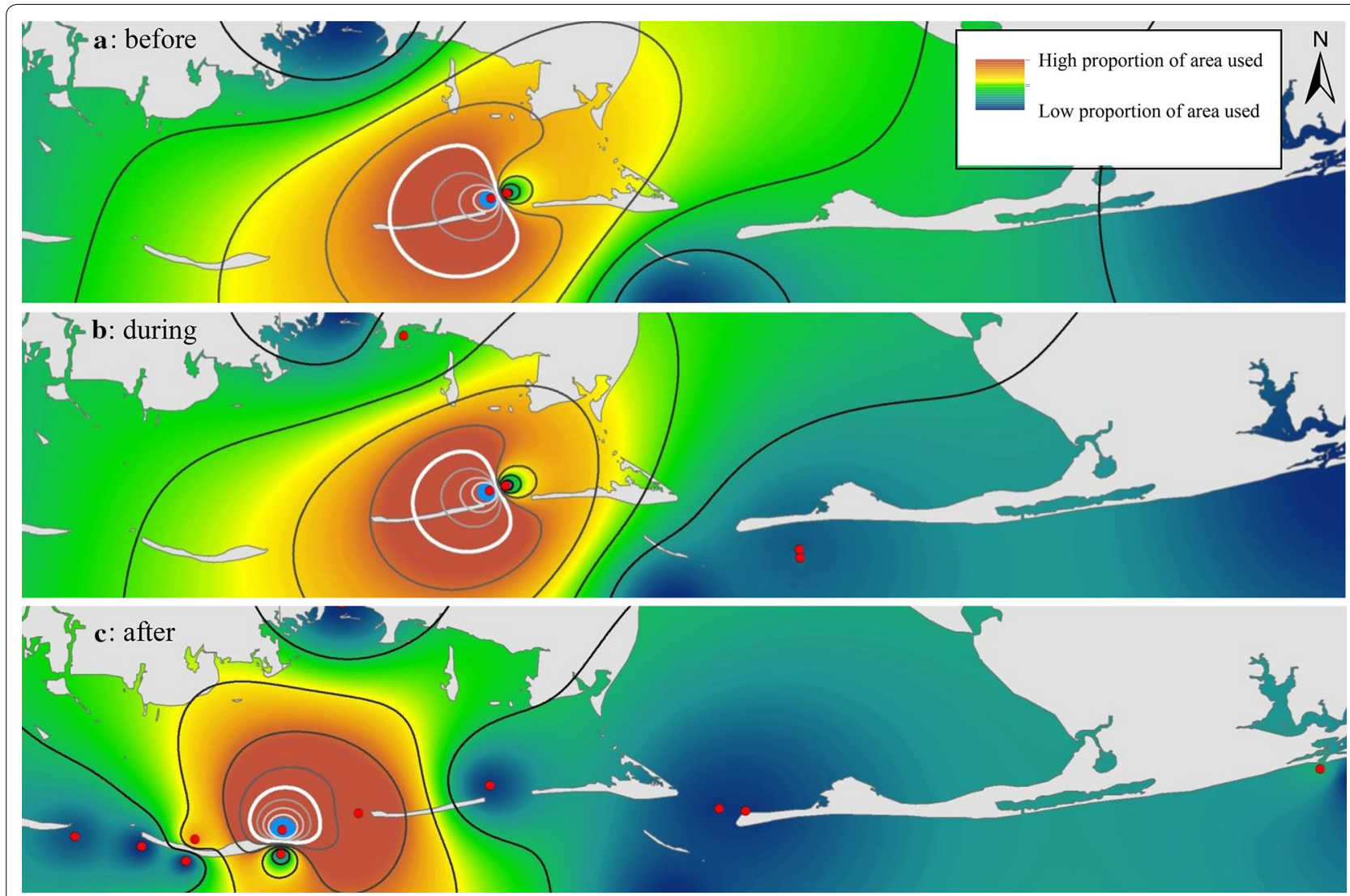

Fig. 5 IDW interpolations for proportion of Bonnethead detections that occurred within the array. Interpolations are based on proportions of Bonnethead detections and represent the time periods a before the closure and construction of the rock-rubble berm at Katrina Cut, $\mathbf{b}$ during construction and Katrina Cut still open, and $\mathbf{c}$ after construction and Katrina Cut was closed off. Red circles indicate receivers wherez Bonnetheads were detected for each time period. White lines represent $50 \%$ locations of highest activity while blue lines represent $90 \%$ locations of highest activity

levels with Katrina Cut open in 2010, but with Katrina Cut closed in 2011-2012, the recovery took a much longer time and often the recovery to pre-peak levels was not complete at the time of the next discharge peak.

On average, salinity was higher in 2010 when Katrina Cut was open. In 2010, surface salinity had a mean value of $28.2( \pm 4.6 \mathrm{SD})$ psu and varied between 4.0 and 35.6 psu. Bottom salinities were similar with a mean value of 31.4 ( $\pm 2.5 \mathrm{SD})$ psu and varied between 6.1 and 35.8 psu. After Katrina Cut was closed in 2011, mean surface salinity decreased to $23.6( \pm 6.5 \mathrm{SD})$ psu and the range was $1.5-33.1 \mathrm{psu}$ while mean bottom salinity decreased to 25.7 ( $\pm 5.3 \mathrm{SD})$ psu and the range was 1.534.1 psu. Over the first five months of 2012, mean surface salinity was $22.5( \pm 5.6 \mathrm{SD})$ psu and the range was 8.2-31.3 psu and mean bottom salinity was 24.9 ( \pm 5.0 $\mathrm{SD}) \mathrm{psu}$ and the range was $8.5-32.2 \mathrm{psu}$.

\section{Discussion}

Our data demonstrate the presence and shifts in movement of Bonnetheads along barrier islands in the northern GOM following an anthropogenic alteration to natural coastline. These findings indicate a relatively rapid shift in Bonnethead movement following the construction of the rock-rubble berm that closed off the passageway of Katrina Cut, suggesting that an anthropogenic modification affected Bonnethead movements.

Barrier islands shift and naturally change geomorphology, often returning to their previous state before a devastating event, such as a hurricane [19]. For example, Dauphin Island, AL was previously fragmented into two islands in the early $1900 \mathrm{~s}$ with an $8.5-\mathrm{km}$-wide channel that eventually filled due to longshore sediment transport during several years without large storms $[18,28$, 29]. Human intervention to accelerate or facilitate natural processes often comes with unanticipated consequences that may affect marine taxa. For example, closing off a corridor between the GOM and Mississippi Sound may negatively affect species using the corridor as a means to ingress into shallower and more protective waters for biological or reproductive strategies. Bonnetheads using Katrina Cut as a means of moving into and out 

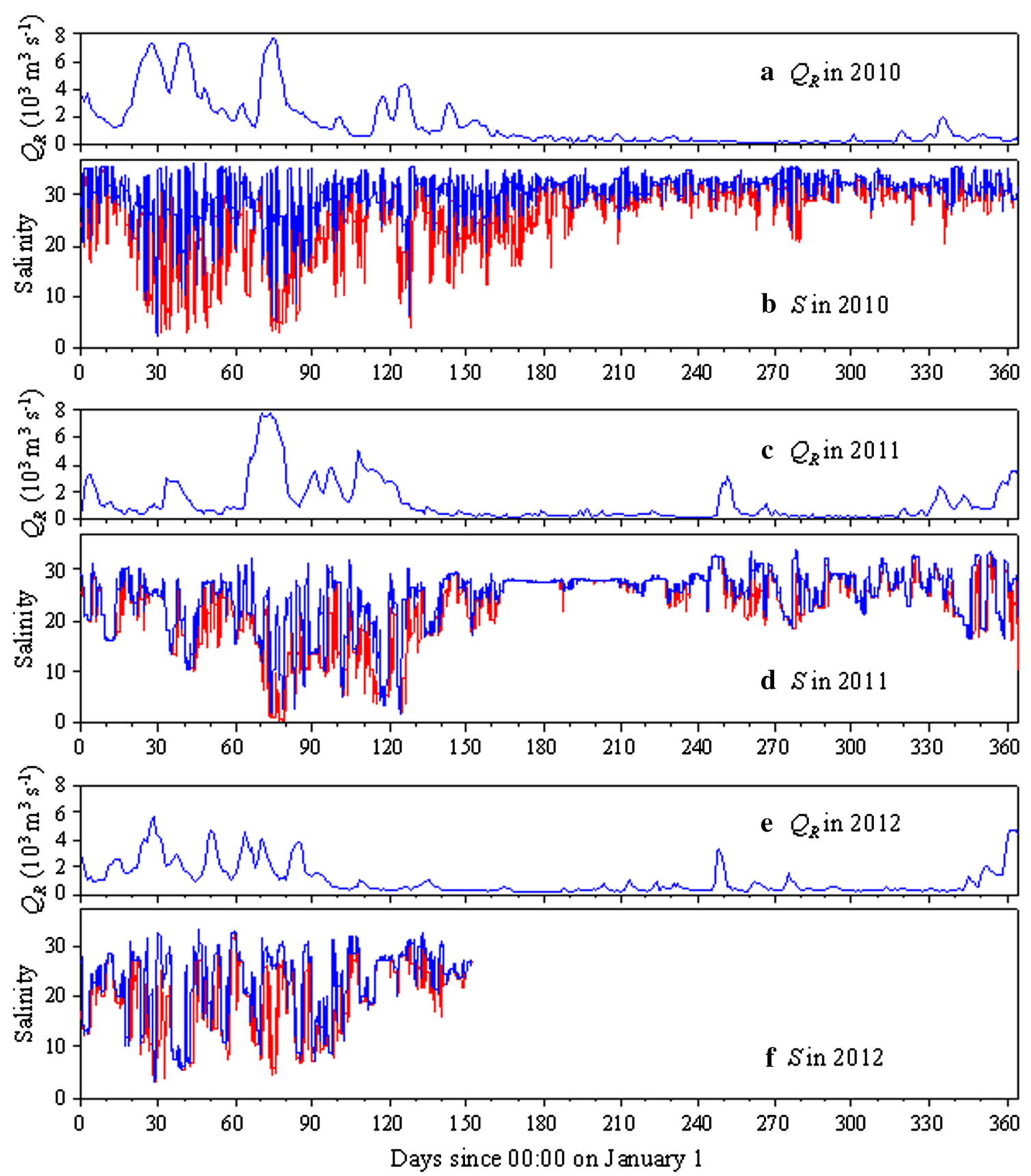

Fig. 6 Three-dimensional hydrodynamic model for salinity. Freshwater discharge and modeled salinity at the surface (red) and bottom (blue) of a location just inside (approximately 50 m) of Katrina Cut. Models were run from January 2010-May 2012 encompassing the entirety of the study. The year 2010 was with Katrina Cut open and the years 2011-2012 were without Katrina Cut (i.e., Katrina Cut closed off). $Q_{R}(\mathbf{a}$, c, e) represents freshwater discharge and $S(\mathbf{b}, \mathbf{d}, \mathbf{f})$ represents salinity

of Mississippi Sound may have been prohibited from reaching an area of preferred habitat, and may have thus shifted movement patterns.

When Katrina Cut was open, Bonnetheads generally remained in a small area near that passageway. The highest proportion of detections occurred at Katrina
Cut when it was open, both before and during construction of the rock-rubble berm, and then decreased in the proportion of detections once the cut was closed. As we observed a relatively rapid decline in the proportion of detections at Katrina Cut following the installation of the rock-rubble berm, we suggest that Bonnetheads were 
using this passageway as a means to enter Mississippi Sound and that the area near Katrina Cut was a preferred habitat. However, the high proportion of detections at Katrina Cut may reflect seasonal habitat use. Bonnetheads have been shown to use estuarine waters more frequently during the summer months [14] and thus our high proportion of detections may be a function of season. In addition, Bonnetheads have been shown to have a high degree of site fidelity to specific estuaries [14]. Since 2010 was the first year of this study, we were unable to examine the degree of site fidelity Bonnetheads exhibit to Katrina Cut. However, we suggest that there is likely some plasticity to Bonnethead site fidelity and that Katrina Cut was a preferred location for Bonnetheads to reside in this region.

Changes in salinity offer the most intuitive explanation for the changes in habitat use shown by tagged Bonnetheads, in line with previous findings for this species [4, $6,15]$. We found that Bonnetheads generally remained at Katrina Cut while the cut was open and made a general westward shift once the cut was closed, as seen from the IDW analysis. The IDW analysis was based on our subset of tagged individuals, and thus areas with higher proportions of use could be biased by the five individuals that we focused on; however, this analysis is a good visual representation of the areas with the highest proportion of use for these individuals. Modeled salinity for 2010, when Katrina Cut was open, demonstrates high-frequency fluctuations in both surface and bottom salinities. Clearly, the presence of Katrina Cut allowed for higher salinity GOM water to be advected into Mississippi Sound by flooding tidal currents, creating high-frequency tidal fluctuations in both surface and bottom salinity. It is important to note that in 2010, salinity was the highest despite the largest freshwater discharge, likely due to the tidal connection with the GOM providing a source of higher salinity water. While we lack a complete set of data to test this relationship, relatively small fluctuations in salinity due to freshwater discharge and tidal cycles may be sufficient to alter Bonnethead movements in our study area.

Salinity may have indirectly altered the distribution of Bonnetheads, through a redistribution of their preferred prey. Previous studies have indicated the importance of prey availability in determining the distribution of coastal sharks [30, 31]. Bonnetheads have been widely documented to consume crustaceans, particularly blue crabs (Callinectes sapidus [32, 33]). It has been suggested that Bonnetheads use estuaries along the east coast as summer feeding grounds, likely due to the high availability of blue crabs [14]. Seagrass is an important habitat for blue crabs [1] and changes in habitat may play a role in prey redistribution. For example, when Katrina Cut was open, shoal grass (Halodule wrightii) was present in large abundance stretching over $6 \mathrm{~km}$ in length for several years while the cut was open (KL Heck unpublished observations). The closure of Katrina Cut was followed by a marked decline in shoal grass (KL Heck unpublished observations), which could potentially alter habitat use by blue crabs. Diet analysis of Bonnetheads in the current study region confirms that Bonnetheads primarily consume portunid crabs, notably blue crabs [Kroetz, unpublished data]. While not directly tested in the current study, a shift in blue crab distribution due to changes in habitat, salinity, dissolved oxygen, or temperature generated by the closure of Katrina Cut may be a factor in the shift in Bonnethead habitat use observed in this study.

Water depth has been identified as an important driver of coastal shark distribution, and is likely species specific [34]. Long-term fisheries independent gillnet surveys conducted in Texas estuaries have shown that the probability of capturing Bonnetheads was highest near tidal inlets with access to deepest waters (>1 m deep, [16]). Katrina Cut was a tidal inlet that was approximately $3 \mathrm{~m}$ deep in the middle of Dauphin Island allowing for swift currents to flow between the two land pieces [20]. Closing off Katrina Cut effectively terminated the tidal inlet and thus reduced the swift currents as well as the higher salinity tidal connection to the GOM. The closure of the tidal inlet may be another driver for the shift in movement that we observed with acoustically tagged Bonnetheads.

During the construction of the rock-rubble berm, cranes, boats, and trucks were continuously present for several months, and these disturbances may have impacted Bonnethead habitat use. In addition to the physical water column disturbance caused by these machines, there was potential for pollution and habitat degradation during the berm construction, and these factors have been shown to affect shark resilience and abundances [5, 35]. While anthropogenic impacts were not found to influence Bonnethead occurrence in FL estuaries [36], Bonnetheads in our study area may have been affected by the continuous, unnatural disturbance.

Knowledge of acoustic detection range when using passive telemetry is critical for the interpretation of animal movements within an array [37]. Many variables can affect detection range (see [37] for a comprehensive review), including properties of the water body such as salinity, temperature, and suspended particles and substrate [38]. A portion of this study included monitoring movements of Bonnetheads during construction of the rock-rubble berm. During construction, sediment, mud, and silt were likely suspended in the water column, which can affect detection range of receivers [38]. For the duration of the construction period, four Bonnetheads were detected at Katrina Cut. The proportion 
of detections that we received during the construction period decreased by half from the proportion we detected before construction at the same receivers. It is possible that Bonnetheads may have been present in the area for longer periods, but decreased acoustic detection range may have precluded their identification. We suggest that future work examining the movements of this species include models that incorporate other potential predictors of movement, such as detection range, temperature, and dissolved oxygen.

\section{Conclusions}

Our data demonstrate a relatively rapid change in habitat use for Bonnetheads, a change that could be due to altered abiotic conditions, changes in water quality, redistribution of preferred prey, or even a decrease in the detection range of our hydrophone array resulting from prolonged construction in the area. Barrier islands are highly dynamic and subject to change either naturally or through anthropogenic modifications. Marine fishes using coastal environments must adapt to changes in their environment or leave the area to find more suitable habitat [5]. Construction of the rock-rubble berm restored habitat at Katrina Cut to a previous state. Historically, it is likely that Bonnetheads have been adapting their movements in accordance with natural shifts in barrier island morphology, albeit on an environmental rather than an anthropogenic time frame. Given the snapshot of data before Katrina Cut was closed off, it is difficult to conclusively identify a single factor that leads to the observed shift in Bonnethead movement. Regardless, we demonstrate that Bonnetheads are capable of rapidly responding to a changing environment, a response that may prove critical in the face of future changes to coastal ecosystems.

\section{Additional file}

Additional file 1. Time lapse of Bonnethead 10143 movements in 2010 and in 2011. The number of detections are scaled to size. Red circles represent detections in 2010 when Katrina Cut was open and green circles represent detections in 2011 when Katrina Cut was closed. The Bonnethead entered the acoustic array in May of 2010, was detected within the array until October of 2010, and returned to the array in April of 2011.

\footnotetext{
Abbreviations

GOM: Gulf of Mexico; DwH: Deepwater Horizon; CAAMP: Coastal Alabama Acoustic Monitoring Program; SAIC: Science Applications International Corporation; WHS: Wireless Hydrophone System; IDW: Inverse Distance-Weighted interpolations.

\section{Authors' contributions}

AMK conceived the study, conducted fieldwork, analyzed and interpreted data, and wrote the manuscript. SPP participated in the conception and design of the study and aided in manuscript preparation. JMD participated in design of the study, data interpretation, and aided in manuscript preparation. KP carried out hydrodynamic model simulations, interpreted the model
}

results, and aided in manuscript preparation. All authors read and approved the final manuscript.

\section{Author details}

1 Department of Marine Sciences, University of South Alabama, LSCB 25, Mobile, AL 36688, USA. ${ }^{2}$ Dauphin Island Sea Lab, 101 Bienville Blvd, Dauphin Island, AL 36528, USA. ${ }^{3}$ Department of Marine Sciences, Texas A\&M University at Galveston, 1001 Texas Clipper Road, OSCB 280, P.O. Box 1675, Galveston, TX 77553, USA.

\section{Acknowledgements}

The authors thank the University of South Alabama and the Dauphin Island Sea Lab for funding this project. The CAAMP array was funded through a grant from the Shelby Center for Ecosystem Based Fishery Management awarded to M Ajemian and JM Drymon. Special thanks are given to A Robydek at SAIC for cooperative sharing of acoustic telemetry data. Thanks are owed to M Ajemian for assistance with this study, A Aven and S Bosarge for assistance with ArcMap, and all of the interns, technicians, and graduate students in the Fisheries Ecology Laboratory at the Dauphin Island Sea Lab for field support. We wish to thank J Carlson and three anonymous reviewers for insightful comments and suggestions that improved this manuscript.

\section{Compliance with ethical guidelines}

\section{Competing interests}

The authors declare that they have no competing interests.

Received: 4 May 2015 Accepted: 3 September 2015

Published online: 30 September 2015

\section{References}

1. Beck MW, Heck KLJ, Able KW, Childers DL, Eggleston DB, Gillanders BM, et al. The identification, conservation, and management of estuarine and marine nurseries for fish and invertebrates. Bioscience. 2001;51:633-41.

2. Cushing DH. Fisheries biology: a study in population dynamics. Madison: University of Wisconsin Press; 1981.

3. Ault JS, Luo J, Wang JD. A spatial ecosystem model to assess spotted seatrout population risks from exploitations and environmental changes. In: Bortone S, editor. Biology of spotted seatrout. Boca Raton: CRC Press; 2003. pp 267-96.

4. Heupel MR, Simpfendorfer CA, Collins AB, Tyminski JP. Residency and movement patterns of bonnethead sharks, Sphyrna tiburo, in a large Florida estuary. Environ Biol Fishes. 2006;76:47-67.

5. Knip DM, Heupel MR, Simpfendorfer CA. Sharks in nearshore environments: models, importance, and consequences. Mar Ecol Prog Ser. 2010;402:1-11.

6. Ubeda AJ, Simpfendorfer CA, Heupel MR. Movements of bonnetheads, Sphyrna tiburo, as a response to salinity change in a Florida estuary. Environ Biol Fishes. 2009:84:293-303.

7. Heupel MR, Simpfendorfer CA. Movement and distribution of young bull sharks Carcharhinus leucas in a variable estuarine environment. Aquat Biol. 2008;1:277-89.

8. Drymon JM, Ajemian MJ, Powers SP. Distribution and dynamic habitat use of young bull sharks Carcharhinus leucas in a highly stratified Northern Gulf of Mexico estuary. PLoS One. 2014;9:e97124.

9. Grubbs RD, Musick JA, Conrath CL, Romine JG. Long-term movements, migration and temporal delineation of a summer nursery for juvenile sandbar sharks in the Chesapeake Bay region. Am Fish Soc Symp. 2007:50:87-107.

10. Seitz JC, Poulakis GR. Anthropogenic effects on the smalltooth sawfish (Pristis pectinata) in the United States. Mar Pollut Bull. 2006;52:1533-40.

11. Reese MM, Stunz GW, Bushon AM. Recruitment of estuarine-dependent nekton through a new tidal inlet: the opening of Packery Channel in Corpus Christi, TX, USA. Estuaries Coasts. 2008;31:1143-57.

12. Compagno LJV. FAO Species catalogue. Vol. 4. Sharks of the world: an annotated and illustrated catalogue of shark species known to date. Part 2. Carcharhiniformes. FAO Fish Synop. 1984;125:251-655.

13. Cortés E, Parsons GR. Comparative demography of two populations of the bonnethead shark (Sphyrna tiburo). Can J Fish Aquat Sci. 1996:53:709-18. 
14. Driggers WB, Frazier BS, Adams DH, Ulrich GF, Jones CM, Hoffmayer ER, Campbell MD. Site fidelity of migratory bonnethead sharks Sphyrna tiburo (L. 1758) to specific estuaries in South Carolina, USA. J Exp Mar Bio Ecol. 2014:459:61-9.

15. Bethea DM, Grace MA. Tag and recapture data for Atlantic Sharpnose, Rhizoprionodon Terraenovae, and Bonnethead Shark, Sphyrna Tiburo, in the Gulf of Mexico and US South Atlantic: 1998-2011. 2013; SEDAR34-WP-04.

16. Froeschke J, Stunz G, Wildhaber M. Environmental influences on the occurrence of coastal sharks in estuarine waters. Mar Ecol Prog Ser. 2010;407:279-92

17. Bethea DM, Ajemian MJ, Carlson JK, Hoffmayer ER, Imhoff JL, Grubbs $\mathrm{RD}$, Peterson $\mathrm{CT}$, Burgess $\mathrm{GH}$. Distribution and community structure of coastal sharks in the northeastern Gulf of Mexico. Environ Biol Fishes. 2014;98:1233-54

18. Conner WH, Day JW, Baumann RH, Randall JM. Influence of hurricanes on coastal ecosystems along the northern Gulf of Mexico. Wetl Ecol Manag. 1989;1:45-56.

19. Froede CR. Changes to Dauphin Island, Alabama, brought about by hurricane Katrina (August 29, 2005). J Coast Res. 2008;24:110-7.

20. Park K, Powers SP, Bosarge GS, Jung HS. Plugging the leak: barrier island restoration following hurricane Katrina enhances larval retention and improves salinity regime for oysters in Mobile Bay Alabama. Mar Environ Res. 2014:94:48-55.

21. McNutt MK, Camilli R, Crone TJ, Guthrie GD, Hsieh PA, Ryerson TB, Savas O, Shaffer F. Review of flow rate estimates of the Deepwater Horizon oil spill. Proc Natl Acad Sci. 2012;109:20260-7.

22. Martínez ML, Feagin RA, Yeager KM, Day J, Costanza R, Harris JA, et al. Artificial modifications of the coast in response to the Deepwater Horizon oil spill: quick solutions or long-term liabilities? Front Ecol Environ. 2012;10:44-9.

23. Ajemian MJ. Foraging ecology of large benthic mesopredators: effects of myliobatid rays on shellfish resources. 2011.

24. Robydek AC, Nunley JM. Determining marine migration patterns and behavior of Gulf Sturgeon in the Gulf of Mexico off Eglin Air Force Base, Florida. 2011

25. South East Data Assessment and Review (SEDAR) 34. Stock assessment report HMS Bonnethead Shark. 2013.

26. Clark E, von Schmidt K. Sharks of the Central Gulf coast of Florida. Bull Mar Sci. 1965:15:13-83.
27. Kim C-K, Park K. A modeling study of water and salt exchange for a micro-tidal, stratified northern Gulf of Mexico estuary. J Mar Syst. 2012;96-97:103-15.

28. Hardin JD, Sapp CD, Emplaincourt JL, Richter KE. Shoreline and bathymetric changes in the coastal area of Alabama. Geol Surv Alabama. 1976; Information Series 50 .

29. Smith WE. Geomorphology of coastal Mobile County, Alabama. Geol Surv Alabama Bull. 1997;162.

30. Torres LG, Heithaus MR, Delius B. Influence of teleost abundance on the distribution and abundance of sharks in Florida Bay, USA. Hydrobiologia. 2006;569:449-55.

31. Drymon JM, Carassou L, Powers SP, Grace M, Dindo J, Dzwonkowski B. Multiscale analysis of factors that affect the distribution of sharks throughout the northern Gulf of Mexico. Fish Bull. 2013;111:370-80.

32. Cortés E, Manire CA, Hueter RE. Diet, feeding habits, and diel feeding chronology of the bonnethead shark, Sphyrna tiburo, in Southwest Florida. Bull Mar Sci. 1996:58:353-67.

33. Bethea DM, Hale L, Carlson JK, Cortés E, Manire CA, Gelsleichter J. Geographic and ontogenetic variation in the diet and daily ration of the bonnethead shark, Sphyrna tiburo, from the eastern Gulf of Mexico. Mar Biol. 2007;152:1009-20.

34. Yates PM, Heupel MR, Tobin AJ, Simpfendorfer CA. Ecological drivers of shark distributions along a tropical coastline. PLoS One. 2015;10:e0121346.

35. Ward-Paige CA, Mora C, Lotze HK, Pattengill-Semmens C, McClenachan L,

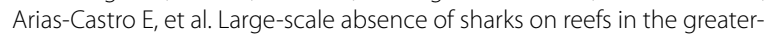
Caribbean: a footprint of human pressures. PLoS One. 2010;5:e11968.

36. Ward-Paige CA, Britten GL, Bethea DM, Carlson JK. Characterizing and predicting essential habitat features for juvenile coastal sharks. Mar Ecol. 2014;1-13.

37. Kessel ST, Cooke SJ, Heupel MR, Hussey NE, Simpfendorfer CA, Vagle S, Fisk AT. A review of detection range testing in aquatic passive acoustic telemetry studies. Rev Fish Biol Fish. 2014;24:199-218.

38. Medwin H, Clay C. Fundamentals of acoustical oceanography. Amsterdam: Elsevier Science; 1997

\section{Submit your next manuscript to BioMed Central and take full advantage of:}

- Convenient online submission

- Thorough peer review

- No space constraints or color figure charges

- Immediate publication on acceptance

- Inclusion in PubMed, CAS, Scopus and Google Scholar

- Research which is freely available for redistribution

Submit your manuscript at 